\title{
Potency of Chitin as an Adsorbent in Black Water Treatment Process at Peatland Environment
}

\author{
Syahmani, \\ Chemistry Education Study Program, \\ Faculty of Teacher Training and Education \\ University of Lambung Mangkurat \\ Banjarmasin, Indonesia \\ syahmani_kimia@unlam.ac.id
}

\author{
Leny, Rilia Iriani, Rahmat Eko Sanjaya \\ Chemistry Education Study Program, \\ Faculty of Teacher Training and Education \\ University of Lambung Mangkurat \\ Banjarmasin, Indonesia
}

\begin{abstract}
The main problem in treatment peat water is related to its specific characteristics, such as low pH (3-4), high organic content, high Fe and Mn content, and dark brown or black water. The objectives of this research are: (1) to determine the potency and effectiveness of chitin as an adsorbent in black water treatment process using column system, and (2) to know the desorption capability of dilute acid toward the $\mathrm{Fe}$ and $\mathrm{Mn}$ cations that adsorbed in chitin column. The results showed that chitin was successfully isolated from shrimp waste by hydrolysis reaction (including three steps namely deproteination, decalcification, and decolorizing). Chitin column system is effective enough to be used as an adsorbent black water. Active sites of chitin (acetamide and hydroxyl) have the ability to adsorb metals contained in the black water of eco-friendly land. The maximum ability of chitin in black water treatment happened at $30 \mathrm{~cm}$ display column and $6 \mathrm{drops} / \mathrm{min}$ for flow rate. In this maximum condition, chitin column ability reduces $\mathrm{Fe}$, Mn, dissolved solids, BOD, COD, pH, temperature, and color

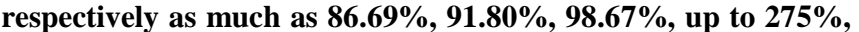
below $99 \%$, neutral pH range, normal air temperature, and colorless. Thus, chitin can be utilized to treat black water until it is suitable to drink. People knowledge about chitin potency as the adsorbent in black water can transform the habit of people around black water environment in using black water. Black water will be used by people around peatland environment after the treatment by chitin as a tool to the black water treatment process.
\end{abstract}

Keywords—black water treatment, adsorbent, column system, chitin

\section{INTRODUCTION}

Nationally, the peatland in Indonesia reaches 20.6 million ha. Peat and swamplands spread over four major islands namely $35 \%$ of it in Sumatra, $32 \%$ in Kalimantan, $3 \%$ in Sulawesi 3\%, and 30\% in Papua. The existence of large peatland, potentially to be exploited in South Kalimantan Province considering its total area is approximately 331,629 ha [1]. Most of South Kalimantan area is the bog where many people around it still uses the bog water that is known as black water, as drinking, bath, and washing. Although, this water still contains many cations and suspended organic matter. The effect of the health complaints suffered by the people are itching, diarrhea, and scaly skin [2]. This can be caused by the water that can be said to be dirty.

Various methods are available for the removal of toxic pollutants from water and wastewater including reverse osmosis, ion exchange, precipitation, electro-dialysis, and adsorption. Recently, various approaches have been studied for the development of cheaper and effective adsorbents. These lowcost adsorbents include natural materials, bio-sorbents, and waste materials resulting from industrial and agricultural activities. These materials can be used as adsorbents for the removal of dyes and ions from solution. Some of the reported adsorbents include agricultural and poultry by-products (eggshell waste, bagasse pith, maize cob, hen feathers, rice husk, and coconut shell), industrial waste products (waste carbon slurries and metal hydroxide sludge), clay materials (bentonite and kaolinite), zeolites, siliceous material (silica beads, alunite, and perlite), bio-sorbents (chitosan, peat, and biomass) and others (starch, cyclodextrin, and cotton), microorganisms such as algae [3-13]. Chitosan has received considerable interest for heavy metals removal due to its excellent metal-binding capacities and low cost, as can be obtained for free from fishery wastes such as shrimp, lobster, and crab shells [14-18].

Cost is actually an important parameter for comparing the adsorbent materials. According to Bailey et al. [19], an adsorbent can be considered a low-cost one if it requires little processing. It is abundant in nature or is a by-product or waste material resulting from another industry. Certain waste products from industrial and agricultural operations, natural materials, and bio sorbents represent potentially economical alternative adsorbents. Many of them have already been tested and proposed for dye and ions removal on water and wastewater decontamination. One of the alternative methods is the use of chitin matter as stationary phase of adsorption column.

The research problems of this study are: (1) How are the potency and effectiveness of chitin as an adsorbent in black water treatment process using column system? and (2) how is the desorption capability of dilute acid toward the Fe and Mn cations that adsorbed in the chitin columns?

The objectives of this study are: (1) to determine the potency and effectiveness of chitin as an adsorbent in black water treatment process using column system, and (2) to 
know the desorption capability of dilute acid toward the Fe and $\mathrm{Mn}$ cations that adsorbed in chitin column.

\section{LITERATURE REVIEW}

\section{A. Chitin}

Chitin is the main constituent polysaccharide of manylegged animal skins (such as crabs), insects, and hard-skinned animals such as shrimp and crabs. Chitin is also found in the cell wall mushroom such as Rhizopus arrhizus, Aspergillus niger, and yeast like Saccharomyces cerevisiae. It is estimated that plants and animals produce more than 100 billion tons of chitin every year and second most biopolymer in nature.

Chitin is a protein-bound polysaccharide. Low protein content caused its easy to deproteination (removal of proteins) and if followed by decalcification (removal of calcium carbonate) on the skin of crustacea, chitin will be obtained. Deproteination uses a base such as $\mathrm{NaOH}$, whereas decalcification uses an acid, such as hydrochloric acid. The structure of chitin is presented in Figure 1.

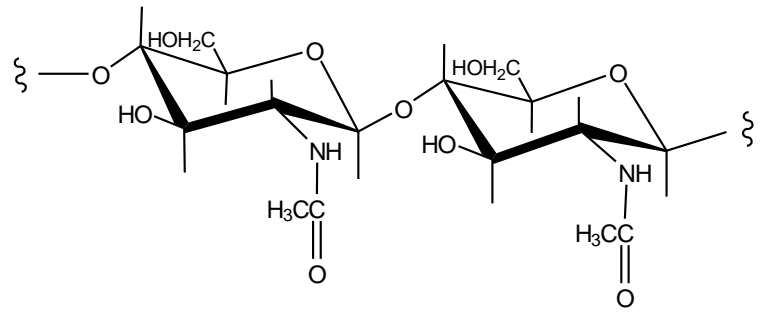

Fig. 1. Chitin structure

\section{B. Adsorption Models}

The adsorption capacity depends on several variables, such as the concentration of the pollutants, the $\mathrm{pH}$ of the medium, the contact time, and the accessibility of the pollutants to the inner surface of the adsorbent, which in turn depends on their size, among others [20]. Langmuir and Freundlich isotherm models are frequently used isotherm models for describing short-term and mono component adsorption of metal ions by different materials [21-24]. The free energy change of sorption can be calculated by Equation (1): $\Delta G^{o}=-R T \ln K$ where $\square G^{0}$ is standard free energy change, $\mathrm{R}$ is the universal gas constant $(8,314 \mathrm{~J} / \mathrm{mole} / \mathrm{K}), \mathrm{T}$ is the absolute temperature and $\mathrm{K}$ is equilibrium constant. $\mathrm{K}$ is the equilibrium constant which is one of the Langmuir parameters. So, by determining K, can also be determined the energy of adsorption process. According to Lynam et. al. [25], the chemical adsorption energy is in the range of 42-420 $\mathrm{KJ} / \mathrm{mole}$, and less than $42 \mathrm{KJ} / \mathrm{mole}$ is the physical adsorption.

\section{Black Water Treatment}

Black water, also called peat water, is a source of surface water found in Kalimantan, dark brown to black (124-850 PtCo), high organic content (138-1560 mg/L $\left.\mathrm{KMnO}_{4}\right)$ and acidic ( $\mathrm{pH} 3,7-5,3)$. The color of this water is caused by high content of dissolved organic matter (humus material), especially in the form of humus acid and its derivatives [26][27]. Besides water is black, the decomposition of organic substances also results in peat water containing high levels of $\mathrm{Fe}$ and $\mathrm{Mn}$ [28]. The water condition indicates that peat water still requires special processing before it can be used as a source of water for domestic purposes.

Peat water is one of the groundwaters that does not meet health requirements but is used by some people who are in tidal areas. This is due to circumstances that do not support for the community to obtain clean water, so people use peat water [29]. Water from the peat areas needs to be specifically processed by increasing the stages in the processing process. The stage is the phase of neutralization of $\mathrm{pH}$ and removes the color. Neutralization processes as well as other processes such as coagulation have been widely reported in the literature. Meanwhile, research on removing peat color in order to improve its quality to clean water is still quite diverse in various methods [30-32]. This is allegedly related to the variety of characteristics/origin of used peat water and methods used. The color of dark chocolate to the blackness of peat water is due to the compound of humification (humic acid and folic acid), besides minerals $\mathrm{Fe}$ and $\mathrm{Mn}$. Both compounds are heterogeneous in molecular weight, carboxyl content, total acidity and solubility in acidic bases.

Black water treatment is highly dependent on the characteristics and quality of water. Black water treatment process is classified into two, (1) Pretreatment. This process can be physical or chemical. Physical treatment is carried out to separate floating substances and suspended solids in black water. In the chemical process, certain chemicals are added to separate solute components examples by chemical precipitation, neutralization, disinfecting and aeration. (2) Ultimate disposal. This treatment is an advanced process aimed at removing organic and inorganic compounds. This process can be done physically, chemically, biologically through filtration, adsorption, reduction-oxidation, and bacteria.

Water treatment is very important to improve the quality of contaminated water sources. The flocculation coagulation stage is an important stage in clean water treatment as it affects the effectiveness of subsequent water treatment stages [28], [33]. and [34]. The use of coagulant alum and PAC (Poly Aluminum Chloride), neutralization, and disinfection is very common to improve the quality of raw water into clean water. It is also expanded in order to treat peat water. Various combinations of methods have been reported in the literature in order to decrease the level of color, organic and inorganic compounds such as filtration, reverse osmosis, and adsorption. The use of a combination of coagulant, $\mathrm{pH}$ neutralizer, and adsorbent is potent enough to improve the quality of peat water into clean water.

One of the recently developed adsorbents is chitin and chitosan. Several studies have led to the role of chitin and chitosan as adsorbents. Nainggolan in Gea [35] reported that chitin had an ability to adsorb polymeric aromatic hydrocarbons (HAP) such as anthracene and chrysene. Reference [36] success make immobilization of humus acid on chitin and applied to the adsorption of $\mathrm{Cr}$ (III). Reference [37] used chitosan column system to adsorb Fe and Mn metals, as well as organic solids from black water. 


\section{Water Quality Standards}

Water quality standards are the parameters used to determine water quality. The water produced must meet quality requirements that include the physical, chemical, microbiological and radioactive requirements as set out in the regulation of the Minister of Health of the Republic of Indonesia No.492/Menkes/Per/IV/2010 concerning Water Quality Requirements. The regulation has been adapted to WHO standard.

\section{E. Knowledge and Cultural Transformation}

The high and low of a civilization reflected from the knowledge of the people. A society that has knowledge, uses that knowledge to build its civilization. In addition, knowledge is the key to the survival of a civilization. History has been proved that knowledge becomes the main pillar in supporting the survival of a civilization. A growing knowledge, participating in giving change a civilization. Thus, knowledge and civilization (culture) are two sides of the inseparable currency.

Hypothesis. The hypotheses in this study were: (1) chitin effectively reduces heavy metals and dissolved solids in black water, (2) reduction of heavy metals and dissolved solids in black water influenced by black water flow velocity and chitin column lengths used, and (3) people knowledge about chitin as tools to black water treatment can transform the people habit in peatland environment.

\section{RESEARCH METHOD}

\section{A. Research Location}

This research was carried out in Chemistry Laboratory, Faculty of Teacher Training and Education University of Lambung Mangkurat Banjarmasin and metal analyzed by AAS in the Health Laboratory Banjarmasin.

\section{B. Research Procedure.}

Chitin isolation is conducted by hydrolysis reaction include three steps namely deproteination using $\mathrm{NaOH} 3.5 \%$, decalcification using $\mathrm{HCl} 1 \mathrm{~N}$ and decolorizing using $\mathrm{NaOCl}$ $2 \%$.

- Pretreatment. Chitin coagulation using poly aluminum chloride (PAC) and filtration. After that neutralization reaction using alkaline. Neutralization reaction aims to have black water with $\mathrm{pH}$ 6-8.

- Preparation of adsorbent in columns. Chitin was dried on the temperature of $60^{\circ} \mathrm{C}$, and followed by sieving on 170 mesh sieve shakers. Then, the column is filled with mush of chitin according to the column length variable.

- Test of optimal column. $50 \mathrm{~mL}$ black water respectively, is flowed pass the columns of chitin with length variation of column 5, 10, 15 and 20 and $25 \mathrm{~cm}$ with flow rate of 10 drop/minute. Then, the concentration of Fe, Mn, and suspended organic matter in the black water determine before and after pass the column. Fe and $\mathrm{Mn}$ were analyzed by AAS and suspended organic matter by evaporation method.

- Test of maximum reduction capability of chitin columns. $50 \mathrm{~mL}$ black water is flowed pass the chitin columns with the optimal length. Then, Fe and Mn cations were analyzed by AAS and suspended organic matter determine by evaporation method.

- Desorption test. Chitin columns adsorbed Fe and Mn cations are eluded with $\mathrm{HNO}_{3}$ 0,5 M. Then, Fe and Mn desorbed in the filtrate determined by AAS.

\section{Data Analysis}

The research data were analyzed by using descriptive method. The reduction capability of chitin columns approach as well as presentation.

(1) column length variable is used to determine the optimal reduction of $\mathrm{Fe}$ and $\mathrm{Mn}$ cations and suspended organic matter in black water.

TABLE 1. REDUCTION CAPABILITY OF CHITIN COLUMN

\begin{tabular}{|c|c|c|c|c|c|c|c|c|}
\hline \multirow{2}{*}{ Parameter } & \multirow{2}{*}{ Unit } & \multicolumn{6}{|c|}{ Column length variation (diameter of $1 \mathrm{~cm}$ ) } & \multirow{2}{*}{ Reduction capability, $\%$} \\
\hline & & K.0 & K.1 & K.2 & K.3 & K.4 & K.5 & \\
\hline $\mathrm{Fe}$ & $\mathrm{mg} / \mathrm{L}$ & 10,3440 & 7,7693 & 1,8129 & 1,9046 & 1,4892 & 1,3772 & 86,69 \\
\hline $\mathrm{Mn}$ & $\mathrm{mg} / \mathrm{L}$ & 0,2000 & 0,0324 & 0,0136 & 0,0166 & 0,081 & 0,0164 & 91,8 \\
\hline Suspended organic matter & $\mathrm{mg} / \mathrm{L}$ & 210 & 40,2 & 67,3 & 21,1 & 5,2 & 2,8 & 98,67 \\
\hline BOD & $\mathrm{mg} / \mathrm{L}$ & 4 & 8 & 5 & 7 & 10 & 11 & 275 \\
\hline COD & $\mathrm{mg} / \mathrm{L}$ & 160 & 88 & 11,2 & 6,4 & 9,6 & 1,6 & 99 \\
\hline Temperature & ${ }^{\circ} \mathrm{C}$ & 29,3 & 28,1 & 27,2 & 27,2 & 27,3 & 27,4 & \\
\hline $\mathrm{pH}$ & - & 3,88 & 4,25 & 5,64 & 6,14 & 6,18 & 6,50 & \\
\hline Color & - & $\begin{array}{c}\text { Dark } \\
\text { brown }\end{array}$ & $\begin{array}{c}\text { Dark } \\
\text { brown }\end{array}$ & $\begin{array}{l}\text { Light } \\
\text { brown }\end{array}$ & $\begin{array}{c}\text { Clear } \\
\text { brown }\end{array}$ & Colorless & Colorless & \\
\hline
\end{tabular}

Description:

K.0 = without flowed chitin column (original sample)

$\mathrm{K} .1$ = flowed chitin column of $5 \mathrm{~cm}$ length

$\mathrm{K} .2$ = flowed chitin column of $10 \mathrm{~cm}$ length

$\mathrm{K} .3$ = flowed chitin column of $15 \mathrm{~cm}$ length

$\mathrm{K} .4$ = flowed chitin column of $20 \mathrm{~cm}$ length $\mathrm{K} .5$ = flowed chitin column of $25 \mathrm{~cm}$ length 
(2) concentration of $\mathrm{Fe}$ and $\mathrm{Mn}$ cations and suspended organic matter reduced is different between concentration before and after passing chitin columns.

\section{RESULT AND DISCUSSION}

\section{A. Chitin Isolate}

Chitin isolated by hydrolysis of shrimp shells waste is the white powder. Chitin rendement counted 70,50\% dry weight. While chitosan obtained from chitin by deacetylation reaction, give rendement of $56 \%$ dry weight.

\section{B. Reduction Capability Test of Chitin Columns}

First, black water sample from Karang Anyar, District of Gambut is analyzed its content include $\mathrm{Fe}, \mathrm{Mn}$ and suspended organic matter, to evaluate how is the water proper or not to be consumed by society. Analyze result as shown in Table 1, composition of Fe, Mn and suspended organic matter in Black Water, are so high according to the drinking water standard. So, it need the treatment before consuming.

After prepared chitin stationary phase in varied length columns of $5,10,15,20,25 \mathrm{~cm}$ respectively, black water sample pass to the column at the flow rate of 10 drops per minute. Data resulted from this test are presented in Table 1.

To determine the effectiveness of chitin column, results of black water treated after passing through the chitin column compared with water quality standard of drinking water. The result is shown in Table 2.

TABLE 2. WATER QUALITY AFTER USING ChITIN COLUMN TOWARDS DRINKING WATER STANDARDS

\begin{tabular}{|l|c|c|c|c|}
\hline & Unit & $\begin{array}{c}\text { Chitin } \\
\text { Column }\end{array}$ & $\begin{array}{c}\text { Chitosan } \\
\text { Column } \\
{[37]}\end{array}$ & $\begin{array}{l}\text { Drinking } \\
\text { Water } \\
\text { Standard } \\
\text { (Permenkes, } \\
\text { 2010) }\end{array}$ \\
\hline $\mathrm{Fe}$ & $\mathrm{mg} / \mathrm{L}$ & $1,3772 *$ & 0,2715 & 0,3 \\
\hline $\mathrm{Mn}$ & $\mathrm{mg} / \mathrm{L}$ & 0,0164 & $<0,002$ & 0,1 \\
\hline $\begin{array}{l}\text { Suspended } \\
\text { organic matter }\end{array}$ & $\mathrm{mg} / \mathrm{L}$ & 2,8 & 0,8 & 1000 \\
\hline BOD & $\mathrm{mg} / \mathrm{L}$ & 11 & 9 & 10 \\
\hline COD & $\mathrm{mg} / \mathrm{L}$ & 1,6 & 0,6 & 20 \\
\hline Temperature & ${ }^{\circ} \mathrm{C}$ & 27,4 & 26,8 & air \\
temperature
\end{tabular}

*not in accordance with drinking water standards

Based on the parameters in Table 2, only Fe is not in accordance with drinking water standards. So this should be addition with an alkaline substance, and the chitin column length for processing $200 \mathrm{~mL}$ of black water is extended so that the Fe metal reduction becomes larger. This condition can be caused treatment process will improve the water quality.

The optimum column length for black water treatment is $25 \mathrm{~cm}$ for the reduction of $\mathrm{Fe}, \mathrm{Mn}$, suspended organic matter, $\mathrm{BOD}, \mathrm{COD}$, temperature, $\mathrm{pH}$, and color. The reduction is due to the binding of the active sites present in chitin (acetamide and hydroxyl groups). Visually, after being treated with a hybrid pretreatment coagulation process and a chitin column system, black water undergoes a reduction in dissolved suspended organic matter, until it becomes clearer. The reduction of suspended organic matter is mainly due to more on the filtration mechanism, whereas chemical interactions can occur, but this is a small opportunity.

The hybrid pretreatment coagulation process and chitin column system can be utilized to treat black water until it is suitable for use as clean water. This is evidenced by the facts of the research, there was improvement of black water quality after being processed by using hybrid pretreatment coagulation process and chitin system. Processed black water undergoes reduction of suspended organic matter, acidity, BOD, COD, temperature, color and cation levels of Fe and Mn. However, technically, the column needs to be tested again because the smaller the particle size will result in a compressed column so that the flow of the solution will be inhibited. Another alternative is a mixture of chitin with other materials such as activated carbon, zeolite or bentonite.

After the black water sample is flowed to the chitin column, based on the continuous adsorption system, some parameters indicate the significant change, namely: (1) reduction of $\mathrm{Fe}$ more than 86,69; (2) reduction of $\mathrm{Mn}$ more than 91,80 ; (3) reduction of suspended organic matter is 98,67 (4) $\mathrm{pH}$ value increased from 3.88 to 6.5 (nearly neutral). From the parameters above, just the $\mathrm{pH}$ that is not suitable for the drinking water standard. So, it has to be alkaline treated to increase $\mathrm{pH}$ until neutral. According to this data, it can be concluded that chitin successfully reduces almost all the parameter observed.

Both of chitin columns have optimum length, $25 \mathrm{~cm}$, for the reduction of $\mathrm{Fe}, \mathrm{Mn}$ and suspended organic matter. Reduction of Fe and Mn cations from the black water caused by chemical interaction between these cations and active sites of chitin (acetamide and hydroxyl) or chitosan (amine and hydroxyl groups). Visually, after treated by chitin column, black water become clearer, that is indicated reducing suspended organic matter. This reducing is mainly predicted through the filtration mechanisms, even though chemical interaction can happen, but with small probability.

\section{Desorption of Fe and Mn Adsorbed by Columns using Dilute Acid}

Nitrite acid 0,5 $\mathrm{M}$ can desorb all the Fe and $\mathrm{Mn}$ adsorbed by column or have $100 \%$ desorption capability, as presented in Table 3. This fact shows that those columns can be recovered, with dilute acid solution before using again and again.

TABLE 3. DESORPTION OF Fe AND Mn ADSORBED BY COLUMNS USING DILUTE ACID

\begin{tabular}{|c|c|c|c|c|}
\hline \multirow{2}{*}{ Parameter } & \multirow{2}{*}{ Unit } & \multicolumn{3}{|c|}{ Desorption capability of dilute acid to chitin } \\
\cline { 3 - 5 } & & $\begin{array}{c}\text { Adsolumns } \\
\text { column }\end{array}$ & Desorption & \% Capability \\
\hline $\mathrm{Fe}$ & $\mathrm{mg} / \mathrm{L}$ & 1,3680 & 1,3680 & 100 \\
\hline $\mathrm{Mn}$ & $\mathrm{mg} / \mathrm{L}$ & 0,6437 & 0,6437 & 100 \\
\hline
\end{tabular}


Chitin has an $\mathrm{N}$-acetyl and hydroxyl group. The presence of these groups on the chains of the chitin molecule, resulting in both being able to act as an electron-pair donor. Based on these properties, chitin has potential as an adsorbent that can interact with metal cations. In solution systems, the interactions between metal and adsorbent can be through physical mechanisms (physical adsorption) or chemical mechanisms (chemical adsorption) or both. Based on the results of [38] heavy metal adsorption energy such as Cd(II) by chitin is chemically interacting because it involves a relatively high adsorption energy of $73 \mathrm{~kJ} / \mathrm{mol}$. According to [25], the chemical adsorption energy is in the range of 42$420 \mathrm{~kJ} / \mathrm{mol}$.

Choline is also a polyelectrolyte that can bind fat and metal contaminants. Chitin has an $\mathrm{N}$-acetyl group in which the $\mathrm{N}$ elements are highly reactive and alkaline. The principle of chitin coagulation is ion exchanger where the amine salt formed by $N$-acetyl reaction with acids will exchange the proton had by the pollutant metal with the electron had by nitrogen $(\mathrm{N})$. Peat water containing metallic pollutants when reacted with chitin, especially with amino groups, it will turn into colloid and colloid is called flocculation. The mechanism of binding of $\mathrm{Fe}$ and $\mathrm{Mn}$ metals from swamp water by chitin is thought to be similar to the mechanism of binding of heavy metals in wastewater by chitosan [39]. In the above case there is a metal bonding by the group $\mathrm{N}$ and $\mathrm{O}$. The metal will be bonded or absorbed, collected and there are metal flocs. Chitin with its binding ability or adsorptive power can be a harmless coagulant.

Generally, this research concludes that chitin isolated from the shrimp shells waste can be used as column filler for treating black water so that it proper to use as source of consumption water. But, technically, it still requires experiment to evaluate particle size factor to avoid pursued column caused by too small size particle. Another alternative is mixture of chitin with other material, for example, active carbon or zeolite.

\section{Society Transformation in Peatland Environment}

People knowledge about use of chitin as a black water adsorbent from peat water can change people's habits in the use of black water or peat water. The success of the column technology using chitin in the purification of black water resulted in public awareness in using black water from peat. The results of this study indicate that black water on peatlands can be used as a source of raw water after the treatment process. Communities around the peat waters, generally using black water or peat water directly without going through water treatment. Knowledge of purifying black water with chitin can change people's habit in using black water. So that people can implement knowledge of black water purification with chitin in everyday life. This kind of society is in line with the opinion expressed by [40], that the cultural transformation of society, began from a deep understanding of a knowledge. With such an understanding, the individual gives new meaning to life, events, and its interaction with others. Once a person understands an in-depth knowledge, he immediately applies the concept, principle or procedure of knowledge to each of his corresponding interactions with others.

\section{CONCLUSION AND SUGGESTION}

Based on this research can be concluded: (1) the maximum ability of chitin in treatment black water happened at $25 \mathrm{~cm}$ display column and 6 drops/min for flow rate. In this maximum condition showed that chitin column ability to reducing $\mathrm{Fe}, \mathrm{Mn}$, dissolved solids, $\mathrm{BOD}, \mathrm{COD}, \mathrm{pH}$, temperature, and color respectively were $86.69 \%, 91.80 \%$, $98.67 \%$, up to $275 \%$, below $99 \%$, neutral $\mathrm{pH}$ range, normal air temperature, and colorless, (2) dilute acid, $\mathrm{HNO}_{3} 0,5 \mathrm{M}$, effectively used for desorption of $\mathrm{Fe}$ and $\mathrm{Mn}$ cations adsorbed by chitin columns with $100 \%$ capability, (3) society knowledge about chitin function to treatment black water, potentially can transform society habit in using black water.

For further research, we can suggest: (1) technically, it needs a test to evaluate particle size factor to avoid pursued column caused by too small size particle or use mixture particle of chitin with other material like active carbon or bentonite, (2) it need to study adsorption mechanism of chitin that are supported by SEM, X-ray diffraction, and chemistry computation data.

\section{ACKNOWLEDGMENT}

This research has been supported by University of Lambung Mangkurat, Indonesia.

\section{REFERENCES}

[1] Balai Besar Penelitian dan Pengembangan Sumber Daya Lahan Pertanian)," Konsorsium Penelitian dan Pengembangan Perubahan Iklim pada Sektor Pertanian,” Laporan Tahun 2008, Bogor, 2008.

[2] D. S. Suhendra, I. Marsaulina and D. N. Santi, "Analysis of peat water quality and health complaint at community on Pulo Gambut Orchard Suka Rame Baru Village Kuala Hulu Sub-district Labuan Batu Utara Regency,"2012.

[3] N. M. Mahmoodi, M. Arami, N. Yousefi Limaee and N. Salman Tabrizi, "Kinetics of heterogeneous photocatalytic degradation of reactive dyes in an immobilized $\mathrm{TiO} 2$ photocatalytic reactor," J. Colloid Interface Sci 295, 2006, pp. 159-164

[4] A. S. Ozcan, B. Erdemand, A. Ozcan, "Adsorption of Acid Blue 193 from aqueous solutions onto BTMA-bentonite," Colloids Surf. A 266, 2005, pp. 73-81

[5] G. Crini and H. N. Peindy, "Adsorption of C. I. Basic Blue 9 on cyclodextrin-based material containing carboxylic groups," Dyes Pigment 70, 2006, pp. 204-211

[6] G. Crini, "Non-conventional low-cost adsorbents for dye removal: a review," Bio resource Technol, 97, 2006, pp 1061-1085

[7] V. K. Gupta, A. Mittal, L. Kurup and J. Mittal, "Adsorption of a hazardous dye, erythrosine, over hen feathers," J. Colloid Interface Sci. 304, 2006, pp. 52-57.

[8] G. Crini and P. M. Badot, "Application of chitosan, a natural amino polysaccharide, for dye removal from aqueous solutions by adsorption processes using batch studies: a review of recent literature," Prog. Polymer. Sci. 39, 2008, pp. 399-447

[9] S. J. T. Pollard, G. D. Fowler, C. J. Sollars and R. Perry, "Low-cost adsorbents for waste and wastewater treatment: a review," Sci. Total Environ. 116, 1992, pp. 31-52

[10] V. K. Gupta and Suhas, "Application of low-cost adsorbents for dye removal: a review," J. Environ. Manage. 90, 2009, pp. 2313-2342

[11] A. Bhatnagar and M. Sillanpaa, "Utilization of agroindustry and municipal wastes as potential adsorbents for water treatment: a review," Chem. Eng. J.157, 2010, pp. 277-296

[12] V. K. Gupta, A. Rastogi and A. Nayak, "Biosorption of nickel onto treated alga (Oedogonium hatei): application of isotherm and kinetic models," J. Colloid Interface Sci. 342, 2010, pp. 533-539 
[13] V. K. Gupta, P. J. M. Carrott, M. M. I. Ribeiro Carrott and Suhas, "Low cost adsorbents: growing approach to wastewater treatment: a review," Crit. Rev. Environ. Sci Technol.39, 2009, pp. 783-842

[14] H. Yoshida and T. Takemori, "Adsorption of direct dye on crosslinked chitosan fiber: breakthrough curve," Water Sci. Technol. 35, 1997, pp. 29-37,

[15] G. Annadurai, "Design of optimum response surface experiments for adsorption of direct dye on chitosan," Bioprocess Eng. 23, 2000, pp. 29-37,

[16] A. G. S. Prado, J. D. Torres, E. A. Faria and S. C. L. Dias, "Comparative adsorption studies of indigo carmine dye on chitin and chitosan,” J. Colloid Interface Sci. 277, 2004, pp. 43-47

[17] G. Annadurai, L. Y. Ling and J. F. Lee, "Adsorption of reactive dye from an aqueous solution by chitosan: isotherm, kinetic and thermodynamic analysis," J. Hazard. Mater. 152, 2008, pp. 337346

[18] S. Rattanaphani, M. Chairat, J. B. Bremnerand V. Rattanaphani, “An adsorption and thermodynamic study of lac dyeing on cotton pretreated with chitosan, "Dyes Pigm. 72, 2007, pp. 88-96,

[19] S. E. Bailey, T. J. Olin, R. M. Brickaand D. D. Adrian, "A review of potentially low-cost sorbents for heavy metals," Water Res. 33, 1999, pp. 2469-2479

[20] T. W. Webi and R. K. Chakravort, "Pore and solid diffusion models for fixed-bed absorbers," AIChE J. 20, 1974, pp. 228-238

[21] Z. Aksu, U. Acikel and T. Kutsal, "Investigation of simultaneous biosorption of copper (II) and chromium (VI) on dried chlorella vulgaris from binary metal mixtures: application of multicomponent adsorption isotherms," Sep. Sci. Technol. 34, 1999, pp. 501-524

[22] Y. Ho, C. T. Huang and H. W. Huang, "Equilibrium adsorption isotherm for metal ions on tree fern," Process Biochem 37, 2002, pp. $1421-1430$

[23] Y. S. Hoand G. Mckay, "The kinetics of sorption of basic dyes from aqueous solution by sphagnum moss peat," Can. J. Chem. Eng.76, 1998, pp. 822-827

[24] B. Yu, Y. Zhang, A. Shukla, S. Shukla, and K. L. Dorris, "The removal of heavy metals from aqueous solutions by sawdust adsorption- removal of lead and comparison of its adsorption with koper,” J. Hazard. Mater. 84, 2001, , pp. 83-94

[25] M. Lynan, J. E. Kilduff and W. J. Weber Jr., "Adsorption of pNitrophenol from dilute aqueous solution," J. Chem. Educ. 72(1), 1995, pp. 80-84,

[26] S. H. Syarfi, "Rejeksi zat organik air gambut dengan membran ultrafiltasi," Jurnal Sains dan Teknologi 12, 2007, , pp. 9-14

[27] G. R. Aiken, R. D. McKnight, Wershaw \& P. McCarthy, "An Introduction to Humic Substances in Soil, Sediment, and Water" in Humic Substance in Soil, Sediment, and Water, Geochemistry, Isolation, and Characterization. G. R. Aiken, D.M. McKnight and R.L. Wershaw, Eds. New York: John Willey, 1985, pp. 533-539
[28] I. Sutapa, "Efisiensi alum sulfat sebagai koagulan dalam proses produksi air bersih, " in Prosiding Seminar Nasional Teknologi Proses Kimia, Jakarta, 2003.

[29] Kusnaedi, Mengolah Air Gambut Dan Air Kotor Untuk Air Minum, Jakarta: Penebar Swadaya, 2006.

[30] N. I. Said, Teknologi Pengolahan Air Minum: Teknologi Pengolahan Air Gambut Sederhana, Jakarta: BPPT Press, 2008.

[31] Alqadrie R. W. N., Sudarmadji \& Yunianto T., "Pengolahan air gambut untuk persediaan air bersih," Teknosains 13(2), 2000.

[32] Mu'min B., "Penurunan zat organik dan warna pada pengolahan air gambut menggunakan membran ultrafiltrasi dengan aliran cross flow yang didahului dengan proses koagulasi/flokulasi dan adsorpsi karbon aktif," Thesis ITB, Bandung, 2002.

[33] R. Xu, Y. P. Zhang and J. Gregory, "Different pollutants removal efficiencies and pollutants distribution with particle size of wastewater treated by CEPT Process, "Water Practice and Technology1(3), 2006, pp. 1-7,

[34] H. Zhan, X. Zhang and X. Zhan, "Coagula-Flocculation mechanism of flocculant and Its physical model,"Separation Technology VI: New Perspectives on Very Large Scale Operations RP3 8, 2004, pp. 1-11

[35] S. Gea, "Pembentukan senyawa kitosan oleh ion logam," Lecture Article, 2000. http://www.usu.ac.id/library.htm/

[36] M. Sehol, "Imobilisasi asam humat pada kitin dan aplikasinya sebagai adsorben Cr (III)" Tesis Program Pascasarjana UGM, Yogyakarta, 2004.

[37] Syahmani, "Aplikasi metode hibrid pretreatment koagulasi dan sistem kolom kitosan sebagai alternatif pengolahan air hitam (Black Water) lahan rawa," dalam Seminar Internasional Etnopedagogi, Banjamasin: FKIP ULM, 2016.

[38] Syahmani \& A. Sholahuddin, "Interaksi Cd(II) dengan kitin dan kitosan isolat limbah kulit udang," Jurnal Kalimantan Scientiae, 25(70), 2007

[39] K. Inoue, Y. Kazuharu and Y. Baba, "Adsorption of metal ion on chitosan and chemically modified chitosan and their application to hydrometallurgy," in Biotechnology and Bioactive Polymers. Gebelein and C. Carraher, Eds. New York: Plenum Publishing, 1994.

[40] M. Dazko, Ken Macur and Sheila Sheiberg, "Transformation: A definition, theory and the challenges to transforming". http://www.mdazko.com/theory_tranformation_final_jan_28_2005.pdf access on 14 Januari 2017 